\title{
ER stress in Alzheimer's disease: a novel neuronal trigger for inflammation and Alzheimer's pathology
} \author{
Antero Salminen*1,2, Anu Kauppinen ${ }^{1}$, Tiina Suuronen ${ }^{1}$, Kai Kaarniranta ${ }^{3,4}$ \\ and Johanna Ojala ${ }^{1}$
}

\begin{abstract}
Address: ${ }^{1}$ Department of Neurology, Institute of Clinical Medicine, University of Kuopio, PO Box 1627, FIN-70211 Kuopio, Finland, ${ }^{2}$ Department of Neurology, University Hospital of Kuopio, PO Box 1777, FIN-70211 Kuopio, Finland, 33epartment of Ophthalmology, Institute of Clinical Medicine, University of Kuopio, PO Box 1627, FIN-70211 Kuopio, Finland and ${ }^{4}$ Department of Ophthalmology, University Hospital of Kuopio, PO Box 1777, FIN-70211 Kuopio, Finland

Email: Antero Salminen* - antero.salminen@uku.fi; Anu Kauppinen - anu.kauppinen@uku.fi; Tiina Suuronen - tiina.suuronen@uku.fi; Kai Kaarniranta - kai.kaarniranta@uku.fi; Johanna Ojala - johanna.ojala@uku.fi

* Corresponding author
\end{abstract}

Published: 26 December 2009

Journal of Neuroinflammation 2009, 6:41 doi:10.1/86/1742-2094-6-4I

Received: 2 December 2009

Accepted: 26 December 2009

This article is available from: http://www.jneuroinflammation.com/content/6/1/4I

(C) 2009 Salminen et al; licensee BioMed Central Ltd.

This is an Open Access article distributed under the terms of the Creative Commons Attribution License (http://creativecommons.org/licenses/by/2.0), which permits unrestricted use, distribution, and reproduction in any medium, provided the original work is properly cited.

\begin{abstract}
The endoplasmic reticulum (ER) is involved in several crucial cellular functions, e.g. protein folding and quality control, maintenance of $\mathrm{Ca}^{2+}$ balance, and cholesterol synthesis. Many genetic and environmental insults can disturb the function of ER and induce ER stress. ER contains three branches of stress sensors, i.e. IREI, PERK and ATF6 transducers, which recognize the misfolding of proteins in ER and activate a complex signaling network to generate the unfolded protein response (UPR). Alzheimer's disease (AD) is a progressive neurodegenerative disorder involving misfolding and aggregation of proteins in conjunction with prolonged cellular stress, e.g. in redox regulation and $\mathrm{Ca}^{2+}$ homeostasis. Emerging evidence indicates that the UPR is activated in neurons but not in glial cells in AD brains. Neurons display pPERK, pelF2 $\alpha$ and pIREI $\alpha$ immunostaining along with abundant diffuse staining of phosphorylated tau protein. Recent studies have demonstrated that ER stress can also induce an inflammatory response via different UPR transducers. The most potent pathways are IREI-TRAF2, PERK-elF2 $\alpha$, PERK-GSK-3, ATF6-CREBH, as well as inflammatory caspase-induced signaling pathways. We will describe the mechanisms which could link the ER stress of neurons to the activation of the inflammatory response and the evolution of pathological changes in AD.
\end{abstract}

\section{Introduction}

Alzheimer's disease (AD) is a progressive neurodegenerative disorder involving a gradual decline in many cognitive processes ultimately leading to dementia. Accumulation of $\beta$-amyloid plaques and neurofibrillary tangles are the well-known histopathological hallmarks of $\mathrm{AD}[1,2]$. It is recognized that increased production, oligomerization and aggregation of amyloid- $\beta$ peptides are the crucial factors in the onset of $\mathrm{AD}$. The toxic amyloid- $\beta$ peptides $A \beta 40$ and $A \beta 42$ are processed from the APP (amyloid- $\beta$ precursor protein) via cleavage by BACE1 ( $\beta$ secretase) and $\gamma$-secretase complexes $[1,3,4]$. APP is a transmembrane protein which is folded and modified in endoplasmic reticulum (ER) and transported through the Golgi complex to the outer membrane. Once on cell surface, APP can be endocytosed and transported to the lysosomal compartment. In the brain, APP is expressed mainly in neurons but astrocytes and oligodendrocytes 
can also express and process APP protein. Currently, it is not clear which cellular compartment processes APP to the toxic amyloid- $\beta$ peptides [3]. It seems that the processing can occur in different compartments during transport from the ER to lysosomes depending on the cellular circumstances, e.g. metabolism and stress conditions. Apparently, oligomerization of amyloid- $\beta$ peptides is important since several studies have demonstrated that oligomers and fibrils are the toxic forms of amyloid- $\beta$ peptides [5]. A number of studies have demonstrated that amyloid- $\beta$ can be oligomerized and localized to intracellular compartments, in particular in $\mathrm{AD}$ [3], which can (i) disturb the function of proteasomes and lysosomes, (ii) impair calcium homeostasis and (iii) enhance the formation of neurofibrillary tangles in neurons (see below).

Accumulation of unfolded or aggregated proteins, increased oxidative stress, and metabolic disturbances are characteristic features of $\mathrm{AD}[1,3]$. ER is a sensitive organelle which can recognize disturbances in cellular homeostasis and therefore it is not surprising that $\mathrm{AD}$ brains display many indications of ER stress [6]. ER can defend the host by activating the UPR (unfolded protein response) including signaling cascades that evoke the adaptive changes in metabolism and gene expression required to manage stress situations. Should a condition become more prolonged or overwhelming, the ER can then trigger the apoptotic program killing the cell but saving the tissue from necrotic injury. Interestingly, recent studies have demonstrated that ER stress can also elicit an innate immunity defence to protect tissues [7]. Currently, it is known that cellular stress triggers the innate immunity system by sending alarming signals, i.e. alarmins [8], or by activating the recognition receptors of inflammasomes [9]. Inflammation is a crucial event in the pathogenesis of $\mathrm{AD}$, but its cause and role in $\mathrm{AD}$ pathogenesis are still controversial [e.g. [10]]. We will describe here the mechanisms which could link ER stress in neurons to activation of inflammatory responses and to the pathological changes observed in $\mathrm{AD}$.

\section{ER stress and UPR signaling}

The ER is a membrane-enclosed reticular network connecting the nuclear envelope to the Golgi complex [11]. It has multiple vital functions: (i) protein folding, posttranslational modification, and transport to the Golgi complex, (ii) maintenance of cellular calcium homeostasis, (iii) synthesis of lipids and sterols, and (iv) regulation of cellular survival via a complex transducer and signaling network [11-16]. ER is a sensitive sensor of cellular homeostasis and different types of insults, e.g. proteasomal inhibition and impaired redox regulation and calcium balance, can disturb the function of ER and induce ER stress (Figure 1). ER stress involves the accumulation of unfolded and deficiently modified proteins, disturbances in lipid metabolism, and release of ER luminal $\mathrm{Ca}^{2+}$ into the cytoplasm $[12,13]$. In particular, failure of protein quality control is detrimental to cellular survival and therefore ER can trigger an evolutionarily conserved UPR to counteract the situation [13-16].

During the last ten years, different branches of ER stress transducers have been identified and recently reviewed in detail [13-16]. Unfolded proteins are recognized in ER via three classes of sensors, (i) IRE1 (inositol-requiring protein-1), (ii) PERK (protein kinase RNA-like ER kinase), and (iii) ATF6 (activating transcription factor-6) (Figure 1 ). The activation mechanism of these proteins has not been totally resolved but it is known that certain molecular chaperones of ER lumen, e.g. BiP (Grp78), are involved in the activation of these transmembrane transducers. The proteins' cytoplasmic domains trigger the specific protein kinase responses or activate transcription factors which can induce the expression of hundreds of target genes. This defence response is called UPR and consists of several chaperone proteins and the proteins of antiapoptotic and antioxidative system. Excessive and prolonged ER stress can ultimately activate apoptotic cell death (Figure 1).

The activation of the IRE1 pathway triggers the dimerization of IRE1 $\alpha$ proteins which stimulates the cytoplasmic kinase domains and subsequently the endoribonuclease domains of the IRE1 $\alpha$ transducer $[15,16]$ (Figure 1). The mRNA of XBP1 (X-box binding protein-1) is the only known substrate of the IRE $1 \alpha$ endoribonuclease. IRE $1 \alpha$ cleaves off one intron from XBP1 mRNA which activates the synthesis of XBP1 protein. XBP1 encodes the transcription factor that trans-activates expression of several UPR target genes. In addition, activated IRE $1 \alpha$ can bind TRAF2 protein (tumor necrosis factor receptor-associated factor 2) which subsequently stimulates stress-kinases, e.g. JNK (c-Jun N-terminal kinase) [16-18], and in this way triggers apoptotic cell death [19] (Figure 1).

The lumenal domain of PERK protein is homologous to that of IRE1 $\alpha$, but the cytoplasmic kinase domain can phosphorylate the $\alpha$-subunit of eIF2 $\alpha$ (eukaryotic translation initiation factor-2) [15,16] (Figure 1). The phosphorylation of eIF $2 \alpha$ protein inhibits the initiation of translation and in this way can alleviate ER stress by reducing the amount of protein transport into the ER. However, some stress-related mRNAs contain upstream sequences that can elevate translational efficiency in association with eIF2 $\alpha$ phosphorylation during ER stress. ATF4 (activating transcription factor 4) is one of these mRNAs and the expression of ATF protein increases not only during ER stress but also in response to many other insults, e.g. hypoxia [20]. ATF4 expression can activate not only a variety of UPR genes but also genes involved in angiogenesis and autophagy [20]. Phosphorylation of 


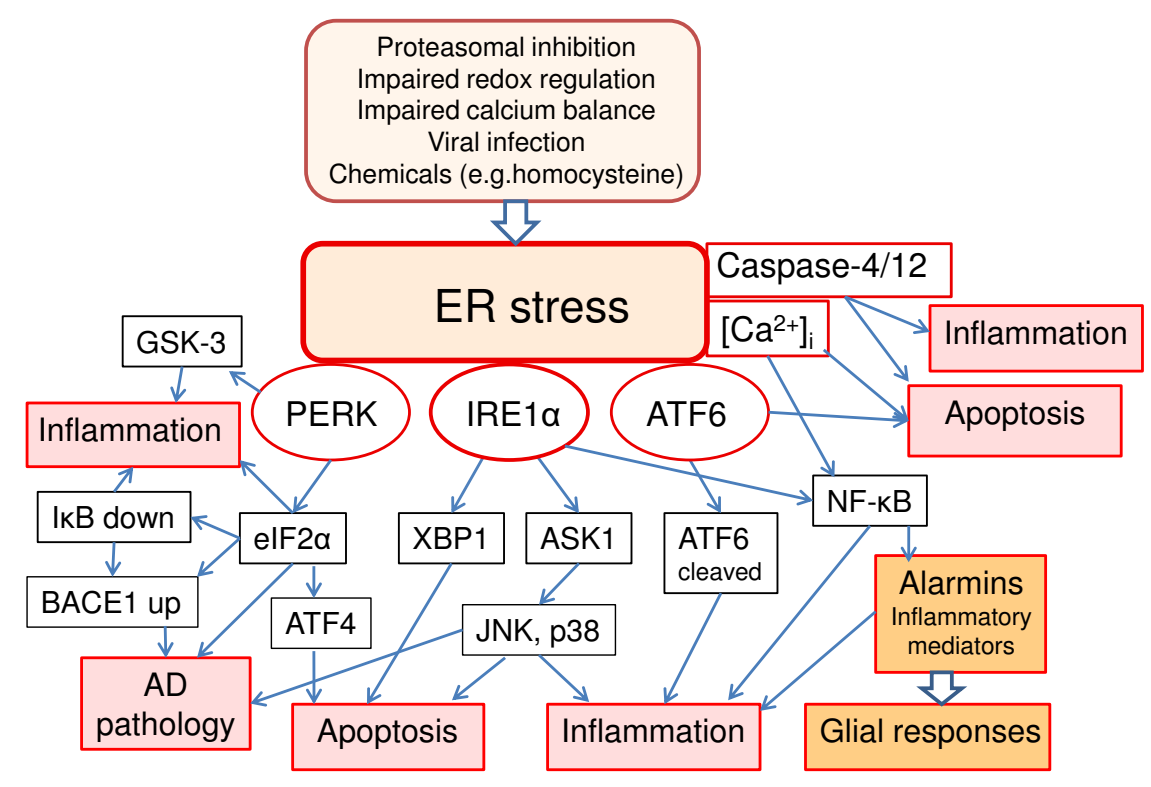

\section{Figure I \\ A schematic presentation of the three branches of UPR, their signaling pathways, and pathological responses with respect to inflammation and AD pathology.}

eIF2 $\alpha$ can also increase the expression of BACE1 via the unique upstream sequences in BACE1 mRNA [21].

The third branch of ER stress transducers includes the ATF6 protein and ATF-related proteins such as the bZIP transmembrane family [22] (Figure 1). Other family members are CREBH, which is expressed only in liver, OASIS, present in astrocytes, and BBF2H7, found in several tissues, e.g. neurons [22,23]. ER stress evokes the translocation of ATF6 molecules from the ER to the Golgi complex where S2P (site 2 protease) cleaves off the cytoplasmic domain which is a bZIP transcription factor. This factor is then transferred to the nucleus where it transactivates a set of UPR genes [22]. There are two ATF6 isoforms, ATF $6 \alpha$ and ATF6 $\beta$, which have opposite effects, i.e. ATF $6 \beta$ is a transcriptional repressor protein balancing the effect of ATF $6 \alpha$ protein [24]. Although the functions of ATF6 branch of ER stress transducers are largely unknown, it seems that ATF6 can activate the expression of only a few UPR genes indicating that ATF6 may have functions other than those related to UPR. Doroudgar et al. [25] observed that ischemia is a sensitive inducer of the ATF6 branch of ER stress responses. Several studies have indicated that the ATF6 family of ER stress transducers can be highly specific with respect to stress signals and the expression pattern of target genes in different tissues [22].

The ER, along with mitochondria, is an important organelle in the regulation of cellular $\mathrm{Ca}^{2+}$ homeostasis [12]. ER is a dynamic $\mathrm{Ca}^{2+}$ store that can quickly trigger intracellular $\mathrm{Ca}^{2+}$ signals but that also can serve as a $\mathrm{Ca}^{2+}$ buffer by removing excessive $\mathrm{Ca}^{2+}$ ions from the cytoplasm. In addition, several ER chaperones and foldases are $\mathrm{Ca}^{2+}$-binding proteins. This folding of proteins requires an oxidizing environment, but oxidative stress itself can induce ER stress and $\mathrm{Ca}^{2+}$ release from the ER [12]. Disturbances in $\mathrm{Ca}^{2+}$ regulation of ER are generally associated with ER stress, and the impaired cross talk between ER and mitochondria is a key component leading to apoptosis $[16,26]$. A large body of evidence has demonstrated that the Bcl-2 (B-cell lymphoma protein 2) family of antiapoptotic proteins can inhibit $\mathrm{Ca}^{2+}$ release from ER in times of cellular stress, leading to apoptosis triggered by mitochondria $[16,26]$. Increased intracellular $\mathrm{Ca}^{2+}$ concentrations can activate several signal pathways, e.g. calpains, calcineurin and phospholipases, which are related not only to apoptosis but also to a variety of physiological and pathological functions [16]. Interestingly, a number of studies have demonstrated that ER stress can activate $\mathrm{NF}-\kappa \mathrm{B}$ signaling following $\mathrm{Ca}^{2+}$ release from the ER and subsequent ROS (reactive oxygen species) production, e.g. in mitochondria [27].

\section{ER stress in Alzheimer's disease}

Neurons are vulnerable to different genetic and environmental insults which affect the homeostasis of ER function via the accumulation of unfolded proteins and disturbances in redox and $\mathrm{Ca}^{2+}$ balances. Therefore, it is not surprising that a number of studies have demonstrated that ER stress is present in several neurodegenerative diseases [28-30]. Evidence of activated UPR signaling has been detected in Alzheimer's, Parkinson's and Hunt- 
ington's diseases, and in ALS (amyotrophic lateral sclerosis) $[6,28-32]$. Furthermore, cerebral ischemia can trigger the UPR, although a concommitant drastic decline in protein synthesis clearly decreases the level of UPR [33]. Viral infections, e.g. Borna virus, can induce prominent ER stress in neurons and subsequently stimulate UPR signaling [34]. In neurons, the tubules and cisternae of ER can extend from the nuclear envelope into dendrites and dendritic spines, and also along axons as far as presynaptic terminals. This means that the neuronal ER is a very specialized organ with functionally different subcompartments $[35,36]$. For example, Murakami et al. [37] revealed that the ER stress response can be localized to dendrites. This heterogeneity of the ER network in neurons may be related to synaptic loss and axonal degeneration [38], particularly in the case of redox-based dysfunctions [36]. Kudo et al. [39] demonstrated that a chemical inducer of BiP chaperone expression could prevent neuronal death in both in vitro and in vivo conditions, emphasizing a role for ER stress in neuronal degeneration.

A large body of evidence indicates that the accumulation of intracellular amyloid- $\beta$ and phosphorylated tau proteins, along with the perturbation of $\mathrm{Ca}^{2+}$ homeostasis, plays a prominent role in the pathogenesis of $\mathrm{AD}[1,3,40]$. Recently, Hoozemans et al. [41] described in detail the changes in neuronal UPR in the brains of AD patients. They observed that immunohistochemical staining of phosphorylated (activated) UPR kinases, pPERK, peIF2 $\alpha$ and $\operatorname{PIRE} 1 \alpha$, was clearly increased in hippocampal neurons in $\mathrm{AD}$, especially in neurons containing granulovacuolar degeneration. Interestingly, pPERK staining was abundant in neurons that showed diffuse staining for phosphorylated tau protein, whereas this staining was less prominent in neurons containing neurofibrillary tangles. The tangles themselves were not stained with PPERK. In particular, in hippocampus the CA1, CA4, and subiculum regions contained an abundance of pPERK-positive neurons. UPR markers showed a granular staining pattern that did not colocalize with ubiquitin or p62 protein, indicating that they were not aggresomes. pPERK-positive neurons also showed abundant staining for GSK-3 $\beta$ (glycogen synthase kinase-3 $\beta$ ). This is an important observation since it indicates that ER stress can activate the expression of GSK-3 $\beta$, a well-known tau kinase, and in that way it could enhance neurofibrillary tangle formation $[42,43]$. Unterberger et al. [44] have also observed that the activations of PERK, eIF2 $\alpha$ and p38 MAPK correlate with the presence of abnormal tau in the neurons of $\mathrm{AD}$ patients. These immunohistochemical studies have revealed the close connection between the ER stress and tau pathology in neurons. Moreover, they demonstrated that UPR-positive staining is localized in neurons but not in glial cells.

\section{ER stress elicits inflammatory response}

The UPR induced by ER stress involves both immediate protein kinase responses and subsequent changes in the expression of hundreds of target genes $[15,16]$. The purpose of these adaptive effects is to restore cellular homeostasis. However, if the provoking stress is prolonged, UPR can trigger the apoptotic cell death program inside the cell. Recent studies have demonstrated that ER stress can also generate signals which alert neighboring cells and elicit an inflammatory response to prevent more extensive tissue damage $[7,45]$. The ability of ER stress to induce an inflammatory response is linked to the pathogenesis of several diseases [46], e.g. obesity-induced ER stress can trigger the inflammatory response and generate peripheral insulin resistance [47]. Moreover, ER stress in liver can activate systemic inflammatory response [22] and it is suggested that ER stress can also induce autoimmune responses [48].

The inflammatory reaction is normally generated by the activation of pattern recognition receptors, e.g. TLRs (Tolllike receptors) and NLRs (NOD-like receptors) which act through signaling cascades, mostly via NF- $\mathrm{kB}$ system, induce an inflammatory response $[49,50]$. Cells suffering stress can also send alarmins which recruit and activate immune cells $[8,51]$. For instance, neuron-glial interactions involve several features which indicate that alarm systems are present in neurodegenerative diseases (see below). Recent studies have revealed that the transducers of ER stress can also trigger signaling pathways which are connected to the induction of inflammatory response. Next, we will discuss the latest studies demonstrating that the UPR is linked to the inflammatory response.

\section{IREI-XBPI pathway}

Activation of IRE1 $\alpha$ triggers the expression of XBP1 protein which switches on the transcription of several UPR genes but which can also stimulate phospholipid synthesis and ER biogenesis [52]. Gargalovic et al. [53] demonstrated that ER stress clearly induces the expression of IL6, IL8, MCP1 (interleukins 6 and 8, monocytes chemoattractant protein-1) and CXCL3 in endothelial cells. The depletion of XBP1 mRNA with siRNA-techniques evokes a significant inhibition in the expression level of these inflammatory mediators [53]. Furthermore, Smith et al. [54] reported that ER stress can strongly potentiate LPS (lipopolysaccharide)-induced secretion of IFN- $\beta$ in macrophages. They observed that this response was dependent on the expression of XBP1 protein, although the effect is likely indirect since the promoter region of IFN- $\beta$ gene does not contain any XBP1 binding sites. On the other hand, Kaser et al. [55] demonstrated that deletion of the $X B P 1$ gene can induce intestinal inflammation. The genetic polymorphism of XBP1 observed in inflammatory bowel disease also supports these results [55]. One could 
argue that these observations are contradictory to the role of XBP1 in provoking inflammation but since XBP1 is a major UPR inducer its deficiency will aggravate ER stress and in that way trigger innate immunity defences. Recently, Hetz et al. [56] demonstrated that deficiency of XBP-1 protects against ALS, a devastating motor neuron disease [57] which also involves the activation of innate immunity [58]. Hetz et al. [56] used transgenic SOD1 mutant mice, a commonly studied mouse model of ALS. They observed that deletion of XBP-1 increases the level of autophagy, which reduces accumulation of aggregated SOD1 proteins and in this way protects motor neurons. However, a prolonged deficiency in UPR defence can be detrimental and induce cell injuries and inflammatory responses, as observed by Kaser et al. [55].

\section{IRE I-TRAF2 pathways}

In 2000, Urano et al. [17] demonstrated that the cytoplasmic domain of IRE1 can recruit the TRAF-2 transducer protein, which can mediate several cellular functions, e.g. apoptosis, inflammation, and metabolism $[59,60]$. Later, it was observed that ASK1 (apoptosis signal-regulating kinase 1) can bind to the complex of IRE1-TRAF2, and ASK1 is an essential kinase in ER stress-induced neuronal death [61]. ASK1 is a member of the MAPKKK family which activates downstream both JNK and p38 MAP kinases and thus induces neuronal apoptosis [62] (Figure 1). Several studies have shown that the IRE1-TRAF2 pathway can activate NF-KB signaling [63-65]. Hu et al. [65] demonstrated that the IRE1-TRAF2 complex recruits the IKK (inhibitory-кB kinase) complex which binds to the TRAF2 component of the complex. The activation of IRE1 in ER stress stimulates IKK kinases which subsequently

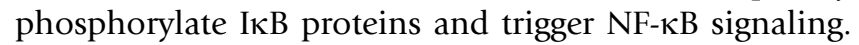
The TRAF2 transducer can interact with several other proteins, e.g. TANK (a TRAF-binding protein) [66] and T2BP [67] which can also trigger NF- $\kappa B$ signaling. The NF- $\kappa B$ system is the major regulator of innate immunity responses in several cell types [68], but JNK can also activate inflammatory responses via the AP-1 transcription factor (activator protein-1) [69]. Interestingly, NF- $\kappa B$ signaling inhibits the JNK activation [70] and prevents neuronal apoptosis and tau pathology induced by the activation of JNK $[62,71]$.

\section{PERK-elF2 $\alpha$ pathway}

PERK is one of the stress kinases that can phosphorylate eIF2 $\alpha$ protein and thus inhibit protein synthesis [72]. Hypoxia, proteasomal inhibition and ultraviolet light also inhibit protein synthesis via activation of the PERK-eIF2 $\alpha$ axis [73-75]. All of these treatments are well-known activators of NF-kB signaling. Deng et al. [76] demonstrated that activation of NF-kB signaling correlates with reduced levels of IкB $\alpha$ protein during inhibition of protein synthesis. The turnover time of IкB $\alpha$ protein is shorter than those

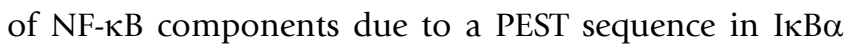
protein $[72,76]$. This is probably a general mechanism during stress since the NF- $\mathrm{KB}$ system has several survival functions in host defence along with innate immunity responses, e.g. the prevention of apoptotic cell death. NF$\kappa B$ signaling can repress expression of GADD153/CHOP (growth arrest and DNA damage/CEBP homology protein), which is the major pro-apoptotic transcription factor induced by ER stress [77].

\section{PERK-GSK-3 pathway}

In addition to eIF2 $\alpha$, PERK has also other target proteins, e.g. GSK-3 [78] (Figure 1). GSK-3 is an interesting kinase in terms of $\mathrm{AD}$ pathology since it is believed to have a major role in the pathogenesis of tau-pathology $[41,43]$. It has been known for many years that GSK-3 $\beta$ can activate NF- $\kappa \mathrm{B}$ signaling and enhance inflammation while lithium, a GSK-3 inhibitor, attenuates inflammatory reactions. Beurel et al. [79] have recently reviewed the crucial role of GSK-3 in the innate and adaptive immune responses. GSK-3 can regulate the function of several inflammation-associated transcription factors, e.g. NF- $\kappa \mathrm{B}$, NFAT and AP-1, but this control is clearly context-dependent [79]. Steinbrecher et al. [80] demonstrated that GSK-3 regulates in a gene-specific manner the recruitment of NF$\kappa \mathrm{B}$ complexes to cytokine promoters. For instance, IL- 6 and MCP-1 require the assistance of GSK-3 $\beta$ for efficient transcription [80]. Demarchi et al. [81] observed that GSK-3 $\beta$ can inhibit the processing of NF- $\mathrm{KB} / \mathrm{p} 105$ into mature $\mathrm{p} 50$ and thus repress NF- $\kappa \mathrm{B}$ activation. It is known that GSK-3 $\beta$ can enhance TWEAK (TNF-like weak inducer of apoptosis)-mediated NF- $\kappa B$ activation in neuroblastoma cells [82]. TWEAK is believed to have a central role in $\mathrm{NF}-\kappa \mathrm{B}$ activation and neuronal death in cerebral ischemia [83].

\section{ATF6/CREBH pathway}

The ATF6 branch of ER stress transducers is not linked to kinase signaling cascades, but trans-activates target gene expression (Figure 1). There have been very few indications that ATF6 could regulate inflammatory genes. However, Zhang et al. [84] demonstrated that in liver ER stress can activate the CREBH transcription factor which induces expression of CRP (C-reactive protein) and SAP (serum amyloid P-component). These acute-phase proteins are well-known mediators of systemic inflammatory responses. Zhang et al. [84] also claimed that activated ATF6 could interact with cleaved CREBH protein and potentiate acute-phase inflammatory responses. They also observed that proinflammatory cytokines and LPS can activate CREBH expression and in this way trigger a systemic inflammatory response. Recently, Yamazaki et al. [85] demonstrated that loss of the ER chaperone GRP78/ Bip activates ATF6-dependent Akt kinase phosphorylation and subsequently triggers NF- $\mathrm{KB}$ signaling in NRK-52E 
cells. It is likely that the ATF6/CREB family of transducers has inflammatory responses but they are tissue-specific as are many other functions of ATF6 (see above).

\section{Inflammatory caspases}

Inflammatory caspases are involved in the maturation of the IL-1 family of cytokines in protein complexes called inflammasomes [86]. This group of caspases consists of caspase 1, 4, 5, 11 (only murine), and 12 . Only caspase- 4 and caspase-12 are activated by ER stress but their function in ER stress is still not defined [86,87]. Several studies have indicated that activation of caspase-12 is related to ER stress-induced apoptotic cell death (Figure 1). However, the activation mechanism is still unknown although some putative mechanisms have been proposed, e.g. via $\mathrm{Ca}^{2+}$ and Hip-2 signaling [88,89]. Wootz et al. [90] demonstrated that XIAP (X-linked inhibitor of apoptosis) can inhibit the activation of caspase-12 in spinal cord of ALS transgenic mice. A greater discrepancy results from the observation that there exists a polymorphism in the human caspase-12 gene that leads to the appearance of the active, ancestral full-length variant, and the inactive, truncated form of caspase-12 in the population [87,91]. It seems that carriers of truncated caspase-12 are more resistant to severe sepsis [92]. The active caspase-12 isoform attenuates inflammatory responses to endotoxin and thus can increase the risk of sepsis. Recently, LeBlanc et al. [92] demonstrated that caspase- 12 inhibits activation of NF- $\mathrm{KB}$ signaling by binding to the NOD-Rip2 complex, which dislocates TRAF6 (TNFR-associated factor) from this complex.

Human caspase- 4 and caspase- 5 are orthologs of mouse inflammatory caspase-11 [86]. Caspase-4 is localized in ER and is activated by the proteolytic cleavage. Several studies have demonstrated that ER stress increases both the expression level and cleavage of caspase- 4 in different experimental models [93-95]. Activation of caspase-4 can trigger either apoptosis or an inflammatory response, or both, depending on the cells involved and the experimental context (Figure 1). Further, caspase- 4 is present in neurons and neuronal stress can activate this caspase and mediate apoptosis, e.g. in INCL (infantile neuronal ceroid lipofuscinosis) and probably in $\mathrm{AD}[95,96]$. The activation mechanism needs to be clarified but it is known to require dimerization and interdomain processing [97] and in that respect differs from the activation of caspase- 1 in inflammasomes [50]. Lakshmanan and Porter [98] observed that LPS-induced NF-кB activation is inhibited in caspase-deficient human THP1 monocytes. They demonstrated that LPS treatment induces binding of caspase4 with TRAF 6 protein and this interaction mediates NF- $\mathrm{kB}$ activation and subsequent cytokine secretion. TRAF- 6 is an important signal transducer between several innate immunity receptors, e.g. Toll/IL-1 family, initiating NF-кB activation via the IKK complex [99]. TRAF6 protein is present in neurons and is known to mediate neurotrophin receptor p75 signaling [100] and certain inflammatory signals during hypoxia and reoxygenation in human NT2 neurons [101].

\section{$\mathrm{Ca}^{2+}$-triggered pathways}

ER stress disturbs cellular $\mathrm{Ca}^{2+}$ homeostasis and triggers oxidative stress $[12,102]$. This type of cellular stress activates the host defence response which is obviously a cellspecific reaction that includes inflammatory responses and ultimately apoptotic cell death (Figure 1). Several studies have indicated that $\mathrm{Ca}^{2+}$ is an important inducer of NF- $\kappa B$ signaling both in ER stress [27] and in the physiological activation of neurons [103]. IP3- (inositol triphosphate-) gated $\mathrm{Ca}^{2+}$ channels have a key role in calcium regulation of neurons and are probably involved in $\mathrm{AD}$ pathogenesis [104]. Schapansky et al. [105] demonstrated that IP3-mediated $\mathrm{Ca}^{2+}$ release, stimulated by amyloid- $\beta$ exposure, increases the DNA-binding activity of the NF- $\mathrm{KB}$ complex. Their results also indicated that activation of NF$\kappa \mathrm{B}$ signaling can inhibit the expression of CHOP (C/EBP homologous protein), a hallmark of ER-stress induced apoptosis. They also observed that the NF- $\mathrm{KB}$ response was even enhanced in presenilin 1-mutant neurons [105]. Nozaki et al. [77] revealed that NF- $\mathrm{B}$ signaling can repress expression of CHOP after different insults which give rise to ER stress in breast cancer cells. It seems that the $\mathrm{NF}-\mathrm{\kappa B}$ activation could represent a survival effect which is linked to the UPR response. In neurons, NF- $\kappa B$ signaling can mediate antiapoptotic responses, increasing the expression of manganese SOD (superoxide dismutase), IAPs (inhibitors of apoptosis), and calbindin [106].

\section{ER stress: neuronal trigger for inflammation and AD pathology? \\ Neuronal ER stress: cause or consequence of AD?}

Immunohistochemical studies have revealed that neurons in postmortem brain samples of $\mathrm{AD}$ patients display prominent expression of markers of ER stress, e.g. pPERK, peIF2 $\alpha$ and pIRE1 $\alpha$ (see above). This is not a surprising result since $\mathrm{AD}$ involves several characteristics that could be inducers of ER stress, e.g. oxidative stress, accumulation of neurofibrillary tangles and even intraneuronal amyloid- $\beta$ aggregates [1-3]. However, there is uncertainty about whether this neuronal ER stress triggers inflammation and $\mathrm{AD}$ pathology or whether it is a consequence of pathological processes in $\mathrm{AD}$ brain.

Genetic studies strongly indicate that amyloid- $\beta$ production, oligomerization and aggregation have a crucial role in the pathogenesis of $\mathrm{AD}$ [1-5]. Recent studies have revealed that oligomers especially are the toxic form of amyloid- $\beta$ in $\mathrm{AD}$ pathogenesis. One key question is whether synthesized APP is cleaved in ER and in this way could trigger amyloid- $\beta$ oligomerization and subsequently an unfolding response in ER. BACE1 and $\gamma$-secre- 
tase are present in ER but it seems that normally amyloid$\beta$ is not cleaved in ER due to (i) the incompatible pH optimum, (ii) the presence of BACE1 stabilizers, e.g. RTN3 and Nogo-B [107], and (iii) the protective acetylation of BACE1 [108]. However, ER is a sensitive stress rheostat that is affected by a number of environmental and cellular insults. These can regulate the function of ER, e.g. by modulating expression of different chaperone molecules or by regulating the capacity for cholesterol synthesis and protein modifications. For instance, Hoshino et al. [109] demonstrated that increased ER chaperone levels can inhibit the production of amyloid- $\beta$. In addition, ER stress has been shown to increase the expression of BACE1 and thus trigger APP processing in ER (see above). Annaert et al. [110] have demonstrated that PS1 can control $\gamma$-secretase activity in pre-Golgi compartments, and PS1 mutations increase amyloid- $\beta$ production in hippocampal neurons of PS1 mutant mice. Ghribi [111] has speculated on several factors that could affect amyloid- $\beta$ processing in ER, such as oxidative stress, disturbances in calcium and cholesterol homeostasis, and trace metals.

ER stress and its effect on cholesterol synthesis can affect trafficking of protein molecules through the ER-Golgi pathway. It is known that seladin-1/DHCR24, a cholesterol-synthesizing enzyme in ER, modulates APP processing and amyloid- $\beta$ production in vivo [112]. Greeve et al. [113] demonstrated that seladin-1 can protect against neurotoxicity induced by amyloid- $\beta$ and oxidative stress. Interestingly, seladin-1 expression is selectively down-regulated in the brain regions affected in AD [113,114]. Furthermore, this reduced expression of seladin-1 is associated with increased hyperphosphorylation of tau protein and neurofibrillary tangles in AD brains [114]. A genetic study also indicated that a polymorphism in the seladin-1 gene could be associated with AD risk [115]. Recently, Sarajärvi et al. [116] demonstrated that downregulation of seladin-1 expression does not affect APP processing in human SH-SY5Y cells over-expressing APP under normal culture conditions. However, in apoptotic conditions induced by staurosporin exposure, reduced levels of seladin-1 clearly increase BACE1 level through protein stabilization and subsequently enhanced cleavage of APP to amyloid- $\beta$ peptide. They also observed that knock-down of seladin-1 expression in apoptotic conditions triggers depletion of GGA3 protein, a Golgi-localized BACE1-sorting protein, via caspase-3 cleavage. Cerebral ischemia, a typical inducer of ER stress, also induces depletion of GGA3 and increases BACE1 levels as well as production of amyloid- $\beta$ [117]. Golgi transport is indispensable for APP processing, and inhibition of Golgi transport, e.g. by treatment with brefeldin A, induces a strong UPR [118]. Interestingly, during stress conditions, APP appears to accumulate in ER or Golgi complex and in this way could trigger ER stress [119].
It seems that ER stress can activate amyloid- $\beta$ production (see above) but, on the other hand, secreted amyloid- $\beta$ can also trigger ER stress [120]. There are clear indications that ER stress inducers have synergistic effects on levels of neuronal UPR, and ultimately can provoke apoptotic cell death [e.g. [121]]. In this respect, it is not surprising that there is evidence that viral infections may trigger $\mathrm{AD}$ pathology, e.g. herpes simplex virus (HSV) [122,123]. Wozniak et al. [123] demonstrated that amyloid- $\beta$ accumulates in neurons infected by HSV and, unexpectedly, they observed that HSV type 1 DNA is present in amyloid plaques in AD brains. This dramatic observation still needs verification. Recently, Ishikawa and Barber [124] described an ER adaptor molecule, STING (stimulator of interferon genes), which can recognize viral infections, e.g. that of HSV, and activate innate immunity signaling via NF- $\kappa$ B and IRF3 pathways. The activation of STING induces expression of type I interferons, IFN- $\alpha$ and IFN- $\beta$, which have both beneficial and pathological effects in CNS, e.g. the overexpression of IFN- $\alpha$ in transgenic mice induces neurodegeneration with loss of cholinergic neurons, gliosis and angiopathy [125], which are also characteristics of AD brain. Another example of the synergistic accumulation of ER stress could be the boxing related disorder dementia pugilistica [126]. Neurotrauma is a powerful inducer of ER stress, and UPR in CNS injuries [127] could trigger $\mathrm{AD}$ via repeated ER stress. Ischemia and hypoxia also induce ER stress and subsequently neuronal cell death [128]. Such pathogenic mechanisms in AD, e.g. those caused by cerebral amyloid angiopathy and microhaemorrhages, could be aggravated by sustained ER stress.

In conclusion, it seems that ER stress can disturb APP processing in neurons, act synergistically with other inducers to stimulate UPR in neurons, and subsequently provoke AD pathology in the context of prolonged stress. On the other hand, AD is known to involve several pathological changes that can trigger ER stress and in that way aggravate $\mathrm{AD}$ pathogenesis. However, neither inflammatory disorders of the CNS nor frontotemporal tauopathies induce $\mathrm{AD}$ pathology, which suggests that amyloid- $\beta$ has a specific role in $\mathrm{AD}$ pathogenesis.

\section{Neuronal ER stress: inducer of inflammation and ADpathology?}

It is obvious that ER stress in neurons can be a crucial factor in the pathogenesis of $\mathrm{AD}$. Activation of the innate immunity system and the appearance of inflammatory responses are closely involved in AD pathology [129]. As described above, there are several pathways associated with UPR that can trigger inflammatory responses as well as apoptotic cell death. There is emerging evidence that the aforementioned inducers of inflammation can be triggered inside of neurons provoked by UPR, as occurs in several other cell types. Generally, it is believed that 
inflammation is a secondary response to secreted amyloid- $\beta$ oligomers and neuronal cell death. In addition, the role of ER stress as a causative factor of sublethal neuronal damage in $\mathrm{AD}$ needs to be addressed.

Innate immunity is a host defence system in tissues, principally the responsibility of specialized immune cells, e.g. microglial cells in the brain. Innate immunity can recognize PAMPs (pathogen-associated molecular patterns) and DAMPs (damage-associated molecular patterns) via PRRs (pattern recognition receptors), such as TLRs and inflammasomal receptors. We have recently reviewed the activation mechanisms of innate immunity in $\mathrm{AD}$ brain $[129,130]$. Several alarmins, i.e. messenger molecules mediating a signal of imminent danger, have been identified [8]. It is obvious that neurons can send alarming signals if there is an aggravating ER stress. Neurons also contain a large set of PRRs [129-131] of which the most interesting may well be the inflammasomal receptors, e.g. NALP1, which can activate inflammatory caspases [see our review [130]]. Several alarmins, e.g. HMGB1 [132] and S100 [133] proteins, are also expressed in neurons. A number of studies have demonstrated that during stress, neurons can express and secrete both cytokines and chemokines [e.g. [134-141]]. Chemokines, e.g. CX3CL1, CCL2, and CCL21, are important alarm molecules in neurons since, after secretion, they can activate glial chemokine receptors $[134,135]$. Chemokines are versatile messengers mediating neuron-glial cell interactions, e.g. they can regulate the proliferation and migration of astrocytes and microglia [134]. However, it seems that neuronal chemokines have both neuroprotective and neurotoxic effects on glial cells.

Neuronal cells can also express and secrete cytokines, e.g. IL-6 [e.g. $[136,137]]$ and TNF- $\alpha[138,139]$, and even complement factors $[140,141]$. Recently, He et al. [142] demonstrated that deletion of TNFR1, a TNF- $\alpha$ responding receptor, can inhibit amyloid- $\beta$ generation and prevent cognitive deficits in $\mathrm{AD}$ mice. This deletion reduced the expression and activity of BACE1 by blocking NF-אB signaling. Such transgenic mice also exhibit a decline in microglial activation and neuronal loss. Janelsins et al. [139] observed that chronic overexpression of neuronal TNF- $\alpha$ enhances local inflammatory responses in transgenic $\mathrm{AD}$ mice. However, there are also reports that the pro-inflammatory cytokine TNF- $\alpha$ has neuroprotective effects in the brain [143].

The NF- $\mathrm{kB}$ transcription factor system is the major signaling pathway evoking the inflammatory responses [68]. NF- $\kappa B$ signaling can also prevent apoptotic signals by inhibiting JNK signaling and stimulating the expression of IAP (inhibitor of apoptosis) proteins [70,144]. ER stress induces several pathways which can activate NF- $\mathrm{\kappa B}$ signaling, (i) IRE1-TRAF2-IKK pathway, (ii) PERK-eIF2 $\alpha$ activa- tion, (iii) PERK-GSK-3 activation, and (iv) $\mathrm{Ca}^{2+-t r i g g e r e d}$ pathways. There are clear indications that these pathways can induce inflammatory responses via NF- $\mathrm{\kappa B}$ signaling in many different cell types (see above). In neurons, the activation of the NF- $\mathrm{BB}$ system is associated with several functions, e.g. neuronal survival and plasticity [145] but also with the signaling of some PRRs [129]. Ridder and Schwaninger [146] have reviewed the role of NF- $\mathrm{KB}$ signaling in cerebral ischemia. In $\mathrm{AD}, \mathrm{NF}-\kappa \mathrm{B}$ signaling can enhance BACE1 expression and thus increase amyloidogenesis [147]. However, prolonged activation of NF- $\mathrm{KB}$ signaling, either via ER stress or inflammatory cytokines, e.g. TNF- $\alpha$, can repress NF- $\mathrm{B}$ signaling. Several studies have demonstrated that persistent ER stress can inhibit inflammatory responses by down-regulating IRE1-TRAF2-mediated IKK activation $[65,148]$. There are several other autoregulatory feedback loops involved in terminating NF- $\kappa B$ signaling [149]. It seems that neurons can protect themselves against overwhelming NF- $\mathrm{KB}$ activation by expressing Sp1-related transcription factors, which can bind to a subset of $\kappa B$ sites and inhibit expression of distinct target genes [150]. The expression levels of Sp3 and Sp4 factors are increased in $\mathrm{AD}$ brains, in particular in neurons containing tau tangles [151]. Several negative feedback systems imply that NF- $\mathrm{kB}$ is an important regulator in neuronal degeneration, either in inflammation or apoptosis.

Inflammatory caspases located in ER, i.e. caspase- 4 and caspase-12 in humans, are another major pathway that can trigger inflammatory responses and apoptosis associated with ER stress (Figure 1, see above). As described earlier, PS1, a co-regulator of $\gamma$-secretase, is present in the ER and can control the processing of APP to amyloid- $\beta$ in the ER [152]. Recently, Rechards et al. [153] demonstrated that PS1 is located in COPI-coated membranes in preGolgi compartments. Yukioka et al. [154] observed that AD-linked PS1 mutation can trigger the cleavage of caspase- 4 and subsequently activate caspase- 3 and caspase- 9 . This is an interesting observation since caspase- 3 can cleave tau protein and induce tangle pathology [155] whereas caspase-4 itself is unable to cut tau protein [155]. Moreover, several other studies have demonstrated that exposing cells to amyloid- $\beta$ induces activation of both caspase- 4 and caspase-12 $[89,96]$. In the case of caspase-12, the amyloid- $\beta$-induced activation seems to be mediated by Hip-2 protein [89]. Moreover, in AD there seems to be a negative feedback to caspase- 4 activation. The amyloidogenic APP cleavage releases AICD (APP intracellular domain) and its interacting partner, FE65 transcription factor, which subsequently can translocate to the nucleus. Kajihara et al. [156] demonstrated that this AICD-FE65 complex can bind to the promoter region of caspase- 4 . They also observed that FE65 factor interacts with Teashirt protein, which recruits histone deacetylases and thus inhibits the transactivation of caspase- 4 . Teashirt is an 
abundant protein in neurons. This indicates that neurons can prevent prolonged, amyloid- $\beta$-induced activation of caspase- 4 and consequent inflammatory and pathological responses in $\mathrm{AD}$.

The IRE1 $\alpha$-TRAF2-ASK1 pathway activates stress kinases $[16,17]$ which have profound functional effects on neuronal homeostasis $[19,59,62]$. ER stress activates ASK1, which subsequently can trigger JNK and p38 MAPK signaling. However, it is still an open question whether ER stress is the only inducer of ASK1. For instance, Kadowaki et al. [157] observed that amyloid- $\beta$ induces neuronal apoptosis through ROS-mediated ASK1 activation rather than via ER stress. However, ER stress can trigger ROS production via $\mathrm{Ca}^{2+}$ mitochondrial signaling. ASK1-mediated JNK activation has great potential to provoke the pathogenesis of AD [158]. This stress kinase signaling can (i) regulate APP processing and induce accumulation of intracellular amyloid- $\beta[159,160]$, (ii) phosphorylate tau protein and trigger aggregation of neurofibrillary tangles $[161,162]$, and (iii) potentiate inflammatory responses via AP-1 activation [18]. In their histopathological study of AD brains, Lagalwar et al. [71] observed that activated pJNK accumulates in granules within hippocampal pyramidal cells. These granules frequently co-localize with granulovacuolar degeneration bodies (GVD) [71] which also contain GSK-3 $\beta$ [163], a well-known PERK target kinase (see above). GVD are large cytoplasmic vacuoles [71] which are reminiscent of the autophagic vacuoles commonly observed in AD [164]. Interestingly, several studies have demonstrated that excessive ER stress can induce autophagic uptake of accumulated material from the overloaded ER [165]. Activated pJNK and pGSK$3 \beta$ are also present in pretangle accumulations of tau protein $[166,167]$, which are different structures from GVDs. Sahara et al. [168] demonstrated that JNK can induce caspase cleavage of tau protein but also that GSK-3 $\beta$ activation is required for tau aggregation.

ER stress can cause $\mathrm{Ca}^{2+}$ efflux from ER and its accumulation in mitochondria. An increased intracellular concentration of $\mathrm{Ca}^{2+}$ induces several pathological responses, observed also in $\mathrm{AD}[40,169]$. However, it is difficult to distinguish the specific role of ER stress in $\mathrm{Ca}^{2+}$-induced disturbances in pathological conditions. It seems that maintenance of $\mathrm{Ca}^{2+}$ balance is important since there are $\mathrm{Ca}^{2+}$-sensitive modulators that can switch off stressrelated signaling pathways. For instance, CIB1 (calcium and integrin binding protein 1) can bind to ASK1 and inhibit its interaction with TRAF2 [170] which blocks the stress-activated MAPK signaling pathway. Another is calnuc (nucleobindin 1) which can inhibit ATF6 activation in ER stress [171]. Calnuc, a $\mathrm{Ca}^{2+}$-binding protein in the Golgi complex, interacts with APP and regulates its processing [172]. Overexpression of calnuc inhibits APP expression and amyloid- $\beta$ production whereas its down- regulation increases cellular levels of APP. Interestingly, levels of calnuc are significantly decreased in $\mathrm{AD}$ brains [172] and this could potentiate amyloid- $\beta$ production.

Neuronal-glial interactions are important regulators of inflammation and $\mathrm{AD}$ pathology. In $\mathrm{AD}$, it seems that $\mathrm{ER}$ stress is a greater threat to neurons than glial cells since UPR is more pronounced in neurons than glial cells (see above). Moreover, ER stress induces in neurons the production of alarmin-type of molecules, e.g. chemokines and cytokines, which affect the function of glial cells. In particular, neuronal chemokines are important messenger molecules between neurons and glial cells [134,135]. Mott et al. [173] observed that neurons can secrete CD22 protein, which inhibits proinflammatory cytokine production in microglia. Other studies have also demonstrated that neurons can suppress microglial activation [174]. This is a logical way to prevent the overactivation of microglia during stress conditions but this immunotolerance may impact detrimentally on microglial cleansing capacity and permit the aggregation of senile plaques. On the other hand, ER stress and UPR may have beneficial feedback effects since ER stress can induce expression of NF- $\mathrm{KB}$ inhibitors, e.g. A20, which is known to generate immunotolerance to certain non-immune cells [148] as well as to suppress the deleterious effects of excessive UPR.

\section{Conclusions}

There are clear indications that ER stress is involved in the pathogenesis of AD. Many of the pathological characteristics of $\mathrm{AD}$, e.g. oxidative stress, impaired $\mathrm{Ca}^{2+}$ homeostasis, intracellular deposition of tau proteins and amyloid- $\beta$ peptides, may be caused by ER stress in neurons but, on the other hand, this kind of pathology can also trigger ER stress and thus aggravate AD pathology. The markers of ER stress in $\mathrm{AD}$ are located in neurons rather than in glial cells. This observation is in agreement with the amyloid hypothesis of AD since misfolded and aggregated proteins are a quality problem in neurons and can trigger cellular defence through UPR. The purpose of this response is to slow down protein synthesis and increase protein folding capacity by increasing the levels of ER and cellular chaperones. In addition, UPR can strengthen the redox defence and buffering capacity of $\mathrm{Ca}^{2+}$, and potentiate cellular cleansing by autophagy. ER stress can also prepare neurons to undergo apoptotic cell death. Interestingly, recent studies have indicated that ER stress can also trigger inflammatory responses to defend brain tissue against necrotic injuries. This response seems to be an alarm type of response involving chemokines and cytokines to activate glial cells.

Excessive and/or prolonged ER stress can be detrimental to neurons since a delayed defence decreases the viability of neurons and can shift the UPR response to switch on an apoptotic program. However, the ER is highly specialized 
in neurons and the level of ER stress can vary among different subcompartments, e.g. in dendrites and axonal synapses. Initial evidence indicates that ER stress can trigger synaptic loss and axonal degeneration. In conclusion, ER stress involves all the elements that can aggravate the pathogenesis of $\mathrm{AD}$.

\section{Competing interests}

The authors declare that they have no competing interests.

\section{Authors' contributions}

AS drafted and edited the manuscript. AK, TS, KK, JO assisted in the planning and editing of the manuscript. All authors read and approved the final manuscript.

\section{Acknowledgements}

This study was financially supported by grants from the Academy of Finland and the University of Kuopio, Finland. The authors thank Dr. Ewen MacDonald for checking the language of the manuscript.

\section{References}

I. Selkoe DJ: Alzheimer's disease: genes, proteins, and therapy. Physiol Rev 200I, 81:74I-766.

2. Tanzi RE, Bertram L: Twenty years of the Alzheimer's disease amyloid hypothesis: a genetic perspective. Cell 2005, 1 20:545-555.

3. LaFerla FM, Green KN, Oddo S: Intracellular amyloid- $\beta$ in Alzheimer's disease. Nat Rev Neurosci 2007, 8:499-508.

4. Thinakaran G, Koo EH: Amyloid precursor protein trafficking, processing, and function. J Biol Chem 2008, 283:296I5-29619.

5. Haass C, Selkoe DJ: Soluble protein oligomers in neurodegeneration: lessons from the Alzheimer's amyloid $\beta$-peptide. Nat Rev Mol Cell Biol 2007, 8: I0I-II 2 .

6. Hoozemans JJM, van Haastert ES, Nijholt DAT, Rozemuller AJM, Eikelenboom $\mathrm{P}$, Scheper $\mathrm{W}$ : The unfolded protein response is activated in pretangle neurons in Alzheimer's disease hippocampus. Am J Pathol 2009, 174:|24|-|25|.

7. Zhang K, Kaufman RJ: From endoplasmic-reticulum stress to the inflammatory response. Nature 2008, 454:455-462.

8. Oppenheim JJ, Tewary P, de la Rosa G, Yang D: Alarmins initiate host defence. Adv Exp Med Biol 2007, 60 I:185-194.

9. Martinon F, Mayor A, Tschopp J: The inflammasomes: guardians of the body. Annu Rev Immunol 2009, 27:229-265.

10. Heneka MT, O'Banion MK: Inflammatory processes in Alzheimer's disease. J Neuroimmunol 2007, 184:69-9I.

II. Baumann O, Walz B: Endoplasmic reticulum of animal cells and its organization into structural and functional domains. Int Rev Cytol 200I, 205: I49-2I4.

12. Gorlach A, Klappa P, Kietzmann T: The endoplasmic reticulum: folding, calcium homeostasis, signaling, and redox control. Antioxid Redox Signal 2006, 8:139|-1418.

13. Schroder M, Kaufman RJ: The mammalian unfolded protein response. Annu Rev Biochem 2005, 74:739-789.

14. Bernales S, Papa FR, Walter P: Intracellular signaling by the unfolded protein response. Annu Rev Cell Dev Biol 2006, 22:487-508.

15. Ron D, Walter $P$ : Signal integration in the endoplasmic reticulum unfolded protein response. Nat Rev Mol Cell Biol 2007, 8:519-529.

16. Kim I, Xu W, Reed JC: Cell death and endoplasmic reticulum stress: disease relevance and therapeutic opportunities. Nat Rev Drug Discov 2008, 7:1013-1030.

17. Urano F, Wang X, Bertolotti A, Zhang Y, Chung P, Harding HP, Ron $D$ : Coupling of stress in the ER to activation of JNK protein kinases by transmembrane protein kinase IREI. Science 2000, 287:664-666.

18. Manning AM, Davis RJ: Targeting JNK for therapeutic benefit: from junk to gold. Nat Rev Drug Discov 2003, 2:554-565.
19. Dhanasekaran DN, Reddy EP: JNK signaling in apoptosis. Oncogene 2008, 27:6245-625I.

20. Ameri K, Harris AL: Activating transcription factor 4. Int J Biochem Cell Biol 2008, 40: 14-2I.

21. O'Connor T, Sadleir KR, Maus E, Velliquette RA, Zhao J, Cole SL, Eimer WA, Hitt B, Bembinster LA, Lammich S, Lichtenthaler SF, Hebert SS, De Strooper B, Haass C, Bennett DA, Vassar R: Phosphorylation of the translation initiation factor elF2 $\alpha$ increases BACEI levels and promotes amyloidogenesis. Neuron 2008, 60:988-1009.

22. Bailey D, O'Hare P: Transmembrane bZIP transcription factors in ER stress signaling and the unfolded protein response. Antioxid Redox Signal 2007, 9:2305-232I.

23. Kondo S, Saito A, Hino S, Murakami T, Ogata M, Kanemoto S, Nara S, Yamashita A, Yoshinaga K, Hara H, Imaizumi K: BBF2H7, a novel transmembrane bZIP transcription factor, is a new type of endoplasmic reticulum stress transducer. Mol Cell Biol 2007, 27:1716-1729.

24. Thuerauf DJ, Morrison L, Glembotski CC: Opposing roles for ATF $6 \alpha$ and $A T F 6 \beta$ in endoplasmic reticulum stress response gene induction. J Biol Chem 2004, 279:21 078-2 I 084.

25. Doroudgar S, Thuerauf DJ, Marcinko MC, Belmont PJ, Glembotski CC: Ischemia activates the ATF6 branch of the endoplasmic reticulum stress response. J Biol Chem 2009, 284:29735-29745.

26. Szegezdi E, MacDonald DC, Chonghaile TN, Gupta S, Samali A: Bcl2 family on guard at the ER. Am J Physiol Cell Physiol 2009, 296:C94I-C953.

27. Pahl HL, Baeuerle PA: The ER-overload response: activation of NF-кB. Trends Biochem Sci 1997, 22:63-67.

28. Lindholm D, Wootz $H$, Korhonen L: ER stress and neurodegenerative diseases. Cell Death Differ 2006, 13:385-392.

29. Paschen W, Mengesdorf T: Cellular abnormalities linked to endoplasmic reticulum dysfunction in cerebrovascular disease - therapeutic potential. Pharmacol Ther 2005, 108:362-375.

30. Scheper W, Hoozemans J]: Endoplasmic reticulum protein quality control in neurodegenerative disease: the good, the bad and the therapy. Curr Med Chem 2009, 16:6I5-626.

3I. Matus S, Lisbona F, Torres M, Leon C, Thielen P, Hetz C: The stress rheostat: an interplay between the unfolded protein response (UPR) and autophagy in neurodegeneration. Curr Mol Med 2008, 8: 157-I72.

32. Kanekura K, Suzuki H, Aiso S, Matsuoka M: ER stress and unfolded protein response in amyotrophic lateral sclerosis. Mol Neurobiol 2009, 39:8I-89.

33. DeGracia DJ, Montie HL: Cerebral ischemia and the unfolded protein response. J Neurochem 2004, 91 : I-8.

34. Williams BL, Lipkin WI: Endoplasmic reticulum stress and neurodegeneration in rats neonatally infected with Borna disease virus. J Virol 2006, 80:8613-8626.

35. Verkhratsky A: Physiology and pathophysiology of the calcium store in the endoplasmic reticulum of neurons. Physiol Rev 2005, 85:20I-279.

36. Banhegyi G, Mandl J, Csala M: Redox-based endoplasmic reticulum dysfunction in neurological diseases. J Neurochem 2008, 107:20-34.

37. Murakami T, Hino SI, Saito A, Imaizumi K: Endoplasmic reticulum stress response in dendrites of cultured primary neurons. Neuroscience 2007, 146:1-8.

38. Raff MC, Whitmore AV, Finn JT: Axonal self-destruction and neurodegeneration. Science 2002, 296:868-87I.

39. Kudo T, Kanemoto S, Hara H, Morimoto N, Morihara T, Kimura R, Tabira T, Imaizumi K, Takeda M: A molecular chaperone inducer protects neurons from ER stress. Cell Death Differ 2008, 15:364-375.

40. Mattson MP, Chan SL: Neuronal and glial calcium signaling in Alzheimer's disease. Cell Calcium 2003, 34:385-397.

4I. Hoozemans JJM, van Haastert ES, Nijholt DAT, Rozemuller AJM, Eikelenboom $\mathrm{P}$, Scheper $\mathrm{W}$ : The unfolded protein response is activated in pretangle neurons in Alzheimer's disease hippocampus. Am J Pathol 2009, I 74: |24|-I25I.

42. Resende R, Ferreiro E, Pereira C, Resende Oliveira C: ER stress is involved in A $\beta$-induced GSK-3 $\beta$ activation and tau phosphorylation. J Neurosci Res 2008, 86:2091-2099.

43. Takashima A: GSK-3 is essential in the pathogenesis of Alzheimer's disease. J Alzheimers Dis 2006, 9(3 Suppl):309-317. 
44. Unterberger U, Hoftberger R, Gelpi E, Flicker H, Budka H, Voigtlander T: Endoplasmic reticulum stress features are prominent in Alzheimer's disease but not in prion diseases in vivo. Neuropathol Exp Neurol 2006, 65:348-357.

45. Kaser A, Blumberg RS: Endoplasmic reticulum stress in the intestinal epithelium and inflammatory bowel disease. Semin Immunol 2009, 21:I56-163.

46. Lin JH, Walter $P$, Yen TSB: Endoplasmic reticulum stress in disease pathogenesis. Annu Rev Pathol 2008, 3:399-425.

47. Hotamisligil GS: Role of endoplasmic reticulum stress and cJun $\mathrm{NH}_{2}$-terminal kinase pathways in inflammation and origin of obesity and diabetes. Diabetes 2005, 54(Suppl 2):S73-78.

48. Todd DJ, Lee AH, Glimcher LH: The endoplasmic reticulum stress response in immunity and autoimmunity. Nat Rev Immunol 2008, 8:663-674.

49. Lee MS, Kim YJ: Signaling pathways downstream of patternrecognition receptors and their cross talk. Annu Rev Biochem 2007, 76:447-480.

50. Martinon F, Mayor A, Tchopp J: The inflammasomes: guardians of the body. Annu Rev Immunol 2009, 27:229-265.

51. Bianchi ME: DAMPs, PAMPs and alarmins: all we need to know about danger. J Leukoc Biol 2007, 8I:I-5.

52. Sriburi R, Jackowski S, Mori K, Brewer JW: XBPI: a link between the unfolded protein response, lipid biosynthesis, and biogenesis of the endoplasmic reticulum. J Cell Biol 2004, 167:35-41.

53. Gargalovic PS, Gharavi NM, Clark MJ, Pagnon J, Yang WP, He A, Truong A, Baruch-Oren T, Berliner JA, Kirchgessner TG, Lusis AJ: The unfolded protein response is an important regulator of inflammatory genes in endothelial cells. Arterioscler Thromb Vasc Biol 2006, 26:2490-2496.

54. Smith JA, Turner MJ, DeLay ML, Klenk El, Sowders DP, Colbert RA: Endoplasmic reticulum stress and the unfolded protein response are linked to synergistic IFN- $\beta$ induction via $X$-box binding protein I. Eur J Immunol 2008, 38: I I94-I 203.

55. Kaser A, Lee AH, Franke A, Glickman JN, Zeissig S, Tilg H, Nieuwenhuis EES, Higgins DE, Glimcher LH, Blumberg RS: XBP I links ER stress to intestinal inflammation and confers genetic risk for human inflammatory bowel disease. Cell 2008, I34:743-756.

56. Hetz C, Thielen P, Matus S, Nassif M, Court F, Kiffin R, Martinez G, Cuervo AM, Brown RH, Glimcher LH: XBP-I deficiency in the nervous system protects against amyotrophic lateral sclerosis by increasing autophagy. Genes Dev 2009, 23:2294-2306.

57. Boillee S, Velde C Vande, Cleveland DW: ALS: A disease of motor neurons and their nonneuronal neighbors. Neuron 2006, 52:39-59.

58. Moisse K, Strong MJ: Innate immunity in amyotrophic lateral sclerosis. Biochim Biophys Acta 2006, I 762: 1083-1093.

59. Bogoyevitch MA, Kobe B: Uses for JNK: the many and varied substrates of the c-Jun $\mathbf{N}$-terminal kinases. Microbiol Mol Biol Rev 2006, 70: $1061-1095$.

60. Chung JY, Lu M, Yin Q, Wu H: Structural revelations of TRAF2 function in TNF receptor signaling pathway. Adv Exp Med Biol 2007, 597:93-II3.

61. Nishitoh H, Matsuzawa A, Tobiume K, Saegusa K, Takeda K, Inoue K, Hori S, Kakizuka A, Ichijo $\mathrm{H}$ : ASKI is essential for endoplasmic reticulum stress-induced neuronal cell death triggered by expanded polyglutamine repeats. Genes Dev 2002, 16:1345-1355

62. Sekine $Y$, Takeda $K$, Ichijo $H$ : The ASKI-MAP kinase signaling in ER stress and neurodegenerative diseases. Curr Mol Med 2006, 6:87-97.

63. Leonardi A, Vito P, Mauro C, Pacifico F, Ulianich L, Consiglio E, Formisano $\mathrm{S}, \mathrm{Di}$ Jeso $\mathrm{B}$ : Endoplasmic reticulum stress causes thyroglobulin retention in this organelle and triggers activation of nuclear factor- $\mathrm{K} B$ via tumor necrosis factor receptor-associated factor 2. Endocrinology 2002, I43:2169-2 I77.

64. Kaneko M, Niinuma $Y$, Nomura Y: Activation signal of nuclear factor- $K B$ in response to endoplasmic reticulum stress is transduced via IREI and tumor necrosis factor receptorassociated factor 2. Biol Pharm Bull 2003, 26:931-935.

65. Hu P, Han Z, Couvillon AD, Kaufman RJ, Exton JH: Autocrine tumor necrosis factor alpha links endoplasmic reticulum stress to the membrane death receptor pathway through IRE I $\alpha$-mediated NF- $\kappa B$ activation and down-regulation of TRAF2 expression. Mol Cell Biol 2006, 26:307I-3084.
66. Cheng G, Baltimore D: TANK, a co-inducer with TRAF2 of TNF- and CD40L-mediated NF-KB activation. Genes Dev 1996, I 0:963-973

67. Kanamori M, Suzuki H, Saito R, Muramatsu M, Hayashizaki Y: T2BP, a novel TRAF2 binding protein, can activate NF- $\kappa$ B and API without TNF stimulation. Biochem Biophys Res Commun 2002, 290: II08-1II3.

68. Vallabhapurapu S, Karin M: Regulation and function of NF-kB transcription factors in the immune system. Annu Rev Immunol 2009, 27:693-733.

69. Lee MS, Kim YJ: Signaling pathways downstream of patternrecognition receptors and their cross talk. Annu Rev Biochem 2007, 76:447-480.

70. Tang G, Minemoto Y, Dibling B, Purcell NH, Li Z, Karin M, Lin A: Inhibition of JNK activation through NF-KB target genes. Nature 200I, 4I 4:3।3-3I7.

7I. Lagalwar S, Berry RW, Binder LI: Relation of hippocampal phosphor-SAPK/JNK granules in Alzheimer's disease and tauopathies to granulovacuolar degeneration bodies. Acta Neuropathol 2007, I I 3:63-73.

72. Laszlo C, Wu S: Old target new approach: an alternate NF-кB activation pathway via translation inhibition. Mol Cell Biochem 2009, 328:9-16.

73. Koumenis C, Naczki C, Koritzinsky M, Rastani S, Diehl A, Sonenberg $\mathrm{N}$, Koromilas A, Wouters BG: Regulation of protein synthesis by hypoxia via activation of endoplasmic reticulum kinase PERK and phosphorylation of the translational initiation factor elF2 $\alpha$. Mol Cell Biol 2002, 22:7405-74I6.

74. Wu S, Tan M, Hu Y, Wang JL, Scheuner D, Kaufman RJ: Ultraviolet light activates NF- $\kappa B$ through translational inhibition of $I \kappa B \alpha$ synthesis. J Biol Chem 2004, 279:34898-34902.

75. Jiang HY, Wek RC: Phosphorylation of the $\alpha$-subunit of the eukaryotic initiation factor-2 (eIF2 $\alpha$ ) reduces protein synthesis and enhances apoptosis in response to proteasome inhibition. J Biol Chem 2005, 280: |4|89-| 4202.

76. Deng J, Lu PD, Zhang Y, Scheuner D, Kaufman RJ, Sonenberg N, Harding HP, Ron D: Translational repression mediates activation of nuclear factor kappa $B$ by phosphorylated translation initiation factor 2. Mol Cell Biol 2004, 24:1016|-10168.

77. Nozaki S, Sledge GW Jr, Nakshatri H: Repression of GADD I53/ CHOP by NF- $\kappa$ B: a possible cellular defence against endoplasmic reticulum stress-induced cell death. Oncogene 200I, 20:2178-2185.

78. Baltzis D, Pluquet O, Papadakis AI, Kazemi S, Qu LK, Koromilas AE: The eIF2 $\alpha$ kinases PERK and PKR activate glycogen synthase kinase 3 to promote the proteasomal degradation of $\mathrm{p} 53$. J Biol Chem 2007, 282:31675-31687.

79. Beurel E, Michalek SM, Jope RS: Innate and adaptive immune responses regulated by glycogen synthase kinase-3 (GSK3). Trends Immunol 2009.

80. Steinbrecher KA, Wilson W III, Cogswell PC, Baldwin AS: Glycogen synthase kinase $3 \beta$ functions to specify gene-specific, NF- $\kappa B$ dependent transcription. Mol Cell Biol 2005, 25:8444-8455.

8I. Demarchi F, Bertoli C, Sandy P, Schneider C: Glycogen synthase kinase-3 $\beta$ regulates NF-KBI/pI 05 stability. J Biol Chem 2003, 278:39583-39590.

82. De Ketelaere A, Vermeulen L, Vialard J, Weyer I Van De, Van Wauwe J, Haegeman G, Moelans I: Involvement of GSK-3 $\beta$ in TWEAKmediated NF- $\kappa$ B activation. FEBS Lett 2004, 566:60-64.

83. Schwaninger $M$, Inta I, Herrmann O: NF- $\mathrm{KB}$ signaling in cerebral ischaemia. Biochem Soc Trans 2006, 34:1291-1294.

84. Zhang K, Shen X, Wu J, Sakaki K, Saunders T, Rutkowski DT, Back $\mathrm{SH}$, Kaufman RJ: Endoplasmic reticulum stress activates cleavage of CREBH to induce a systematic inflammatory response. Cell 2006, I 24:587-599.

85. Yamazaki H, Hiramatsu N, Hayakawa K, Tagawa Y, Okamura M, Ogata R, Huang T, Nakajima S, Yao J, Paton AW, Paton JC, Kitamura $M$ : Activation of the Akt-NF-KB pathway by subtilase cytotoxin through the ATF6 branch of the unfolded protein response. J Immunol 2009, I 83:|480-| 487.

86. Martinon F, Mayor A, Tschopp J: The inflammasomes: guardians of the body. Annu Rev Immunol 2009, 27:229-265.

87. Nadiri A, Wolinski MK, Saleh M: The inflammatory caspases: key players in the host response to pathogenic invasion and sepsis. J Immunol 2006, 177:4239-4245. 
88. Momoi T: Caspases involved in ER stress-mediated cell death. J Chem Neuroanat 2004, 28: I0I-I05.

89. Song S, Lee H, Kam TI, Tai ML, Lee JY, Noh JY, Shim SM, Seo SJ, Kong YY, Nakagawa T, Chung CW, Choi DY, Oubrahim H, Jung YK: E225K/Hip-2 regulates caspase- 12 in ER stress-mediated $A \beta$ neurotoxicity. J Cell Biol 2008, I 82:675-684.

90. Wootz H, Hansson I, Korhonen L, Lindholm D: XIAP decreases caspases- 12 cleavage and calpain activity in spinal cord of ALS transgenic mice. Exp Cell Res 2006, 3 I 2:1890-1898.

91. Saleh M, Vaillancourt JP, Graham RK, Huyck M, Srinivasula SM, Alnemri ES, Steinberg MH, Nolan V, Baldwin CT, Hotchkiss RS, Buchman TG, Zehnbauer BA, Hayden MR, Farrer LA, Roy S, Nicholson DW: Differential modulation of endotoxin responsiveness by human caspases-1 2 polymorphisms. Nature 2004, 429:75-79.

92. LeBlanc PM, Yeretssian G, Rutherford N, Doiron K, Nadiri A, Zhu L, Green DR, Gruenhaid S, Saleh M: Caspase- 12 modulates NOD signaling and regulates antimicrobial peptide production and mucosal immunity. Cell Host Microbe 2008, 3:I46-157.

93. Hitomi J, Katayama T, Eguchi Y, Kudo T, Taniguchi M, Koyama Y, Manabe T, Yamagishi S, Bando Y, Imaizumi K, Tsujimoto $Y$, Tohyama $M$ : Involvement of caspases-4 in endoplasmic reticulum stress-induced apoptosis and $\mathbf{A} \beta$-induced cell death. J Cell Biol 2004, 165:347-356.

94. Hidvegi T, Schmidt BZ, Hale P, Perlmutter DH: Accumulation of mutant $\alpha I$-antitrypsin $Z$ in the endoplasmic reticulum activates caspases -4 and $-\mid 2$, NF- $K B$, and BAP $3 \mid$ but not the unfolded protein response. J Biol Chem 2005, 280:39002-390I5.

95. Kim S], Zhang Z, Hitomi E, Lee YC, Mukherjee AB: Endoplasmic reticulum stress-induced caspases- 4 activation mediates apoptosis and neurodegeneration in INCL. Hum Mol Genet 2006, I 5: I826-1834.

96. Katayama T, Imaizumi K, Manabe T, Hitomi J, Kudo T, Tohyama M: Induction of neuronal death by ER stress in Alzheimer's disease. I Chem Neuroanat 2004, 28:67-78.

97. Karki P, Dahal GR, Park IS: Both dimerization and interdomain processing are essential for caspases-4 activation. Biochem Biophys Res Commun 2007, 356:1056-1061.

98. Lakshmanan U, Porter AG: Caspase-4 interacts with TNF receptor-associated factor 6 and mediates lipopolysaccharideinduced NF- $\kappa$ B-dependent production of IL-8 and CC chemokine ligand 4 (macrophage-inflammatory protein-I $\beta$ ). J Immunol 2007, 179:8480-8490.

99. Chen ZJ: Ubiquitin signaling in the NF-kB pathway. Nat Cell Biol 2005, 7:758-765.

100. Yeiser EC, Rutkoski NJ, Naito A, Inoue J, Carter BD: Neurotrophin signaling through the p75 receptor is deficient in traf6-/mice. J Neurosci 2004, 24:1052I-10529.

10I. Froyland E, Skjaret C, Wright MS, Dalen ML, Cvancarova M, Kasi C, Rootwelt T: Inflammatory receptors and pathways in human NT2-N neurons during hypoxia and reoxygenation. Impact of acidosis . Brain Res 2008, 1 21 7:37-49.

102. Malhotra JD, Kaufman RJ: Endoplasmic reticulum stress and oxidative stress: a vicious cycle or a double-edged sword? Antioxid Redox Signal 2007, 9:2277-2293.

103. Meffert MK, Baltimore D: Physiological functions for brain NFKB. Trends Neurosci 2005, 28:37-43.

104. Stutzmann GE: Calcium dysregulation, IP3 signaling, and Alzheimer's disease. Neuroscientist 2005, I I: I I0- I I5.

105. Schapansky J, Olson K, Ploeg R Van Der, Glazner G: NF-кB activated by $E R$ calcium release inhibits $A \beta$-mediated expression of CHOP protein: enhancement by AD-linked mutant presenilin I. Exp Neurol 2007, 208:169-I76.

106. Mattson MP, Culmsee C, Yu Z, Camandola S: Roles of nuclear factor $\kappa B$ in neuronal survival and plasticity. J Neurochem 2000, 74:443-456.

107. Tang BL, Liou YC: Novel modulators of amyloid- $\beta$ precursor protein processing. I Neurochem 2007, 100:3 |4-323.

108. Ko MH, Puglielli L: Two endoplasmic reticulum (ER)/ER Golgi intermediate compartment-based lysine acetyltransferases post-translationally regulate BACEI levels. J Biol Chem 2009, 284:2482-2492.

109. Hoshino T, Nakaya T, Araki W, Suzuki K, Suzuki T, Mizushima T: Endoplasmic reticulum chaperones inhibit the production of amyloid- $\beta$ peptides. Biochem J 2007, 402:58I-589.

110. Annaert WG, Levesque L, Craessaerts K, Dierinck I, Snellings G, Westaway D, St. George-Hyslop P, Cordell B, Fraser P, De Strooper
B: Presenilin I controls $\gamma$-secretase processing of amyloid precursor protein in pre-Golgi compartments of hippocampal neurons. J Cell Biol 1999, I 47:277-294.

III. Ghribi O: The role of the endoplasmic reticulum in the accumulation of $\beta$-amyloid peptide in Alzheimer's disease. Curr Mol Med 2006, 6: I 19-133.

II2. Crameri A, Biondi E, Kuehnle K, Lutjohann D, Thelen KM, Perga S, Dotti CG, Nitsch RM, Ledesma MD, Mohajeri MH: The role of seladin-I/DHCR24 in cholesterol biosynthesis, APP processing and $A \beta$ generation in vivo. EMBO J 2006, 25:432-443.

1 13. Greeve I, Hermans-Borgmeyer I, Brellinger C, Kasper D, Gomez-Isla T, Behl C, Levkau B, Nitsch RM: The human DIMINUTO/ DWARFI homolog seladin-I confers resistance to Alzheimer's disease-associated neurodegeneration and oxidative stress. J Neurosci 2000, 20:7345-7352.

II4. livonen S, Hiltunen M, Alafuzoff I, Mannermaa A, Kerokoski P, Puoliväli J, Salminen A, Helisalmi S, Soininen H: Seladin-I transcription is linked to neuronal degeneration in Alzheimer's disease. Neuroscience 2002, I | 3:301-3 I0.

1 15. Lämsä R, Helisalmi S, Hiltunen M, Herukka SK, Tapiola T, Pirttilä T, Vepsäläinen $\mathrm{S}$, Soininen $\mathrm{H}$ : The association study between DHCR24 polymorphisms and Alzheimer's disease. Am J Med Genet Part B 2007, I 44B:906-910.

II6. Sarajärvi T, Haapasalo A, Viswanathan J, Mäkinen P, Laitinen M, Soininen H, Hiltunen M: Down-regulation of seladin-I increases BACEI levels and activity through enhanced GGA3 depletion during apoptosis. J Biol Chem 2009, 284:34433-34443.

117. Tesco G, Koh YH, Kang EL, Cameron AN, Das S, Sena-Esteves M, Hiltunen M, Yang SH, Zhong Z, Shen Y, Simpkins JW, Tanzi RE: Depletion of GGA3 stabilizes BACE and enhances betasecretase activity. Neuron 2007, 54:72I-737.

118. Citterio C, Vichi A, Pacheco-Rodriguez G, Aponte AM, Moss J, Vaughan M: Unfolded protein response and cell death after depletion of Brefeldin A-inhibited guanine nucleotideexchange protein GBFI. Proc Natl Acad Sci USA 2008, 105:2877-2882.

119. Domingues SCTS, Henriques AG, Wu W, da Cruz e Silva EF: Altered subcellular distribution of the Amyloid precursor protein under stress conditions. Ann NY Acad Sci 2007, 1096: $184-195$

120. Pereira C, Ferreiro E, Cardoso SM, de Oliveira CR: Cell degeneration induced by amyloid- $\beta$ peptides: implications for Alzheimer's disease. J Mol Neurosci 2004, 23:97-104.

121. Kim HJ, Cho HK, Kwon YH: Synergistic induction of ER stress by homocysteine and $\beta$-amyloid in SH-SY5Y cells. J Nutr Biochem 2008, 19:754-76I.

122. Itzhaki RF, Wozniak MA: Herpes simplex virus type I, apolipoprotein $E$, and cholesterol: a dangerous liaison in Alzheimer's disease and other disorders. Prog Lipid Res 2006, 45:73-90.

123. Wozniak MA, Mee AP, Itzhaki RF: Herpes simplex virus type I DNA is located within Alzheimer's disease amyloid plaques. J Pathol 2009, 21 7: |3|-138.

124. Ishikawa H, Barber GN: STING is an endoplasmic reticulum adaptor that facilitates innate immune signalling. Nature 2008, 455:674-678.

125. Campbell IL, Krucker T, Steffensen S, Akwa Y, Powell HC, Lane T, Carr DJ, Gold LH, Henriksen SJ, Siggins GR: Structural and functional neuropathology in transgenic mice with CNS expression of IFN- $\alpha$. Brain Res 1999, 835:46-6I.

126. Jordan BD: Chronic traumatic brain injury associated with boxing. Semin Neurol 2000, 20: 179-185.

127. Larner SF, Hayes RL, Wang KKW: Unfolded protein response after neurotrauma. I Neurotrauma 2006, 23:807-829.

128. Ogawa S, Kitao Y, Hori O: Ischemia-induced neuronal cell death and stress response. Antioxid Redox Signal 2007, 9:573-587.

129. Salminen A, Ojala J, Kauppinen A, Kaarniranta K, Suuronen T: Inflammation in Alzheimer's disease: amyloid- $\beta$ oligomers trigger innate immunity defence via pattern recognition receptors. Prog Neurobiol 2009, 87: 18I-194.

130. Salminen A, Ojala J, Suuronen T, Kaarniranta K, Kauppinen A: Amyloid- $\beta$ oligomers set fire to inflammasomes and induce Alzheimer's pathology. J Cell Mol Med 2008, I 2:2255-2262.

I3I. van Noort JM, Bsibsi M: Toll-like receptors in the CNS: implications for neurodegeneration and repair. Prog Brain Res 2009, 175:139-148. 
132. Kim JB, Lim CM, Yu YM, Lee JK: Induction and subcellular localization of high-mobility group box-I (HMGBI) in the postischemic rat brain. J Neurosci Res 2008, 86: II25-II3I.

133. Rickmann M, Wolff JR: S 100 protein expression in subpopulations of neurons of rat brain. Neuroscience 1995, 67:977-991.

134. de Haas AH, van Weering HRJ, de Jong EK, Boddeke HWGM, Biber $\mathrm{KPH}$ : Neuronal chemokines: versatile messengers in central nervous system cell interaction. Mol Neurobiol 2007, 36:137- $15 \mid$

135. Biber K, Vinet J, Boddeke HWGM: Neuron-microglia signaling: chemokines as versatile messengers. J Neuroimmunol 2008, 198:69-74.

136. Li Y, Barger SW, Liu L, Mrak RE, Griffin WS: SI00 $\beta$ induction of proinflammatory cytokine interleukin-6 in neurons. J Neurochem 2000, 74: $143-150$.

137. Suzuki S, Tanaka K, Nagata E, Ito D, Dembo T, Fukuuchi Y: Cerebral neurons express interleukin-6 after transient forebrain ischemia in gerbils. Neurosci Lett 1999, 262:1 17-120.

138. Liu T, Clark RK, McDonnell PC, Young PR, White RF, Barone FC, Feuerstein GZ: Tumor necrosis factor- $\alpha$ expression in ischemic neurons. Stroke 1994, 25:|48|-| 488.

139. Janelsins M, Mastrangelo MA, Park KM, Sudol KL, Narrow WC, Oddo S, LaFerla FM, Callahan LM, Federoff HJ, Bowers WJ: Chronic neuron-specific tumor necrosis factor- $\alpha$ expression enhances the local inflammatory environment ultimately leading to neuronal death in 3xTg-AD mice. Am J Pathol 2008, I73: I768-I782.

140. Shen Y, Li R, McGeer EG, McGeer PL: Neuronal expression of mRNAs for complement proteins of the classical pathway in Alzheimer brain. Brain Res 1997, 769:391-395.

141. Thomas A, Gasque P, Vaudry D, Gonzalez B, Fontaine M: Expression of a complete and functional complement system by human neuronal cells in vitro. Int Immunol 2000, I 2:1015-1023.

142. He P, Zhong Z, Lindholm K, Berning L, Lee W, Lemere C, Staufenbiel $M$, Li R, Shen Y: Deletion of tumor necrosis factor death receptor inhibits amyloid $\beta$ generation and prevents learning and memory deficits in Alzheimer's mice. J Cell Biol 2007, 178:829-84I.

143. Figiel I: Pro-inflammatory cytokine TNF- $\alpha$ as a neuroprotective agent in the brain. Acta Neurobiol Exp (Wars) 2008, 68:526-534.

144. Dutta J, Fan Y, Gupta N, Fan G, Gelinas C: Current insights into the regulation of programmed cell death by NF- $\kappa B$. Oncogene 2006, 25:6800-6816.

145. Mattson MP, Culmsee C, Yu Z, Camandola S: Roles of nuclear factor $\kappa B$ in the neuronal survival and plasticity. I Neurochem 2000, 74:443-456.

146. Ridder DA, Schwaninger M: NF- $\kappa$ B signaling in cerebral ischemia. Neuroscience 2009, 158:995-1006.

147. Rossner S, Sastre M, Bourne K, Lichtenthaler SF: Transcriptional and translational regulation of BACEI expression - implications for Alzheimer's disease. Prog Neurobiol 2006, 79:95-III.

148. Hayakawa K, Hiramatsu N, Okamura M, Yamazaki H, Nakajima S, Yao J, Paton AW, Paton JC, Kitamura M: Acquisition of anergy to proinflammatory cytokines in nonimmune cells through endoplasmic reticulum stress response: a mechanism for subsidence of inflammation. J Immunol 2009, 182:1 I82-II91.

149. Renner F, Schmitz ML: Autoregulatory feedback loops terminating the NF- $\kappa$ B response. Trends Biochem Sci 2008, 34: I 28- I 35.

150. Mao XR, Moerman-Herzog AM, Chen Y, Barger SW: Unique aspects of transcriptional regulation in neurons - nuances in NF-KB and SpI-related factors. I Neuroinflam 2009, 6:16.

15I. Boutillier S, Lannes B, Buee L, Delacourte A, Rouaux C, Mohr M, Bellocq JP, Sellal F, Larmet Y, Boutillier AL, Loeffler JP: Sp3 and Sp4 transcription factor levels are increased in brains of patients with Alzheimer's disease. Neurodegener Dis 2007, 4:4I3-423.

152. Xia W, Zhang J, Ostaszewski BL, Kimberly WT, Seubert P, Koo EH, Shen J, Selkoe DJ: Presenilin I regulates the processing of $\beta$ amyloid precursor protein C-terminal fragments and the generation of amyloid $\beta$-protein in endoplasmic reticulum and Golgi. Biochemistry 1998, 37:16465-1647I.

153. Rechards M, Xia W, Oorschot V, van Dijk S, Annaert W, Selkoe DJ, Klumperman J: Presenilin- I-mediated retention of APP derivatives in early biosynthetic compartments. Traffic 2006, 7:354-364
154. Yukioka F, Matsuzaki S, Kawamoto K, Koyama Y, Hitomi J, Katayama T, Tohyama M: Presenilin-I mutation activates the signaling pathway of caspase-4 in endoplasmic reticulum stressinduced apoptosis. Neurochem Int 2008, 52:683-687.

155. Rissman RA, Poon WW, Blurton-Jones M, Oddo S, Torp R, Vitek MP, LaFerla FM, Rohn TT, Cotman CW: Caspase-cleavage of tau is an early event in Alzheimer disease tangle pathology. J Clin Invest 2004, I I 4: I2I-130.

156. Kajihara Y, Akram A, Katsel P, Haroutunian V, Schmeidler J, Beecham G, Haines JL, Pericak-Vance MA, Buxbaum JD: FE65 binds teashirt, inhibiting expression of the primate-specific caspase-4. PloS One 2009, 4:e507I.

157. Kadowaki H, Nishitoh H, Urano F, Sadamitsu C, Matsuzawa A, Takeda K, Masutani H, Yodoi J, Urano Y, Nagano T, Ichijo H: Amyloid $\beta$ induces neuronal cell death through ROS-mediated ASKI activation. Cell Death Differ 2005, I 2:19-24.

158. Okazawa $H$, Estus S: The JNK/c-Jun cascade and Alzheimer's disease. Am J Alzheimers Dis Other Demen 2002, I7:79-88.

159. Shoji M, Iwakami N, Takeuchi S, Waragai M, Suzuki M, Kanazawa I, Lippa CF, Ono S, Okazawa H: JNK activation is associated with intracellular $\beta$-amyloid accumulation. Brain Res Mol Brain Res 200I, 85:22I-223.

160. Colombo A, Bastone A, Ploia C, Sclip A, Salmona M, Forloni G, Borsello $\mathrm{T}$ : JNK regulates APP cleavage and degradation in model of Alzheimer's disease. Neurobiol Dis 2009, 33:5 I8-525.

161. Reynolds CH, Utton MA, Gibb GM, Yates A, Anderton BH: Stressactivated protein kinase/c-Jun $\mathbf{N}$-terminal kinase phosphorylates $\tau$ protein. J Neurochem 1997, 68:1736-1744.

162. Vogel J, Anand VS, Ludwig B, Nawoschik S, Dunlop J, Braithwaite SP: The JNK pathway amplifies and drives subcellular changes in tau phosphorylation. Neuropharmacology 2009, 57:539-550.

163. Leroy K, Boutajangout A, Authelet M, Woodgett JR, Anderton BH, Brion JP: The active form of glycogen synthase kinase- $3 \beta$ is associated with granulovacuolar degeneration in neurons in Alzheimer's disease. Acta Neuropathol 2002, 103:91-99.

164. Nixon RA: Autophagy, amyloidogenesis and Alzheimer disease. J Cell Sci 2007, | 20:408|-409|.

165. Yorimitsu T, Klionsky DJ: Eating the endoplasmic reticulum: quality control by autophagy. Trends Cell Biol 2007, 17:279-285.

166. Zhu X, Raina AK, Rottkamp CA, Aliev G, Perry G, Boux H, Smith MA: Activation and redistribution of c-Jun $\mathbf{N}$-terminal kinasel stress activated protein kinase in degenerationg neurons in Alzheimer's disease. J Neurochem 200I, 76:435-44I.

167. Ishizawa T, Sahara N, Ishiguro K, Kersh J, McGowan E, Lewis J, Hutton M, Dickson DW, Yen SH: Co-localization of glycogen synthase kinase-3 with neurofibrillary tangles and granulovacuolar degeneration in transgenic mice. Am J Pathol 2003, 163: $1057-1067$

168. Sahara N, Murayama M, Lee B, Park JM, Lagalwar S, Binder LI, Takashima A: Active c-Jun $\mathbf{N}$-terminal kinase induces caspase cleavage of tau and additional phosphorylation by GSK-3 $\beta$ is required for tau aggregation. Eur J Neurosci 2008, 27:2897-2906.

169. Bezprozvanny I, Mattson MP: Neuronal calcium mishandling and the pathogenesis of Alzheimer's disease. Trends Neurosci 2008, 31:454-463.

170. Yoon KW, Cho JH, Lee JK, Kang YH, Chae JS, Kim YM, Kim J, Kim EK, Kim SE, Baik JH, Naik UP, Cho SG, Choi EJ: CIB I functions as a $\mathrm{Ca2+-sensitive} \mathrm{modulator} \mathrm{of} \mathrm{stress-induced} \mathrm{signaling} \mathrm{by}$ targeting ASKI. Proc Natl Acad Sci USA 2009, 106: I 7389- 17394.

17I. Tsukumo Y, Tomida A, Kitahara O, Nakamura Y, Asada S, Mori K, Tsuruo T: Nucleobindin I controls the unfolded protein response by inhibiting ATF6 activation. J Biol Chem 2007, 282:29264-29272.

172. Lin P, Li F, Zhang Y, Huang H, Tong G, Farquhar MG, Xu H: Calnuc binds to Alzheimer's $\beta$-amyloid precursor protein and affects its biogenesis. J Neurochem 2007, 100:1505-1514.

173. Mott RT, Ait-Ghezala G, Town T, Mori T, Vendrame M, Zeng J, Ehrhart J, Mullan M, Tan J: Neuronal expression of CD22: Novel mechanism for inhibiting microglial proinflammatory cytokine production. Glia 2004, 46:369-379.

174. Chang RC, Chen W, Hudson P, Wilson B, Han DS, Hong JS: Neurons reduce glial responses to lipopolysaccharide (LPS) and prevent injury of microglial cells from over-activation by LPS. J Neurochem 200I, 76: 1042-1049. 